\title{
PENGARUH LKS IPA TERPADU BERMUATAN KETERAMPILAN LITERASI TEMA GERAK DALAM KEHIDUPAN TERHADAP KOMPETENSI SISWA KELAS VIII SMPN 8 PADANG
}

\author{
Yosa Aulya Putri $^{1)}$, Asrizal Asrizal ${ }^{2)}$, Yulkifli Yulkifli ${ }^{2)}$ \\ ${ }^{1)}$ Mahasiswa Pendidikan Fisika, FMIPA Universitas Negeri Padang \\ ${ }^{2)}$ Staf Pengajar Jurusan Fisika, FMIPA Universitas Negeri Padang \\ yosaaulyaputri03@gmail.com \\ asrizal_unp@yahoo.com \\ yulkifliamir@gmail.com
}

\begin{abstract}
In the 2013 curriculum, science teaching is conducted in integrated patter and it is supported by the school literacy movement to improve competence of students. Integrated science teaching is expected to improve three competencies of students including attitude, knowledge, and skill. However, the real conditions in school show that integrated science teaching and school literacy movement can't implemented optimally. One solution that can be done is to use the integrated science student worksheet by integrating the skills literacy on motion theme in life. The purpose of this research was to investigate the influence of the use of Integrated science student worksheet by integrating the skills literacy of motion themes in life toward the competences of grade VIII students in SMPN 8 Padang. The type of research which conducted can be grouped into quasi experiment type with one group one group pretest-posttest design. Samples were obtained by using the purposive sampling technique. The research instruments consist of observation sheet for attitude competency, written test for knowledge competency and performance assessment for skill competency. Data analysis which used in this research consist of descriptive statistical analysis, simple linear regression analysis, significant relationship test and comparison test. Based on the result of data analysis can be stated that the use of integrated science student worksheet by integrating the skills literacy gives significant influence on the competence of knowledge and skill of grade VIII students respectively $38.44 \%$ and $35.05 \%$. In addition, the use of integrated science student worksheet also gives a significant influence on the attitude of the grade VIII students in SMPN 8 Padang.
\end{abstract}

Keywords : Integrated Science, Student Worksheet, Skills Literacy, Motion Theme

\section{PENDAHULUAN}

Abad ke-21 merupakan abad pengetahuan. Pada abad ini terdapat informasi yang sudah banyak ter sebar dengan mudah dan teknologi yang berkembang dengan pesat. Perkembangan Ilmu Pengetahuan dan Teknologi (IPTEK) yang semakin canggih memung kinkan terjadinya persaingan yang begitu ketat. Pada abad ini diperlukan Sumber Daya Manusia (SDM) yang memiliki kualitas untuk dapat menghadapi per saingan tersebut agar bertahan dan mampu berkompe tensi secara sehat.

Perkembangan IPTEK yang semakin canggih didukung oleh berbagai media untuk penyebarluasan informasi. Pesatnya kemajuan IPTEK tidak terlepas dari perkembangan dunia pendidikan. Pendidikan harus memiliki literasi yang baik untuk dapat mem persiapkan dalam menghadapi persaingan pada abad ini. Kemampuan yang harus dimiliki tersebut untuk mengolah dan memahami informasi cerdas berkenaan dengan isu-isu penting yang melibatkan IPTEK. Dengan adanya literasi, seseorang akan mam pu mengidentifikasi, mencari, menemukan, meng evaluasi, dan memanfaatkan informasi yang diterima nya baik secara langsung maupun tidak langsung. Pentingnya literasi dikarenakan semakin baiknya nilai literasi siswa, maka hasil belajar siswa akan semakin meningkat ${ }^{[1]}$. Tinggi dan rendahnya nilai literasi tersebut berpengaruh pada daya saing bangsa dalam persaingan global. Oleh sebab itu, kemampuan literasi sangat penting dalam pendidikan untuk membantu keberhasilan individu dan negara yang berbasis pengetahuan.

Pendidikan saat ini perlu menjawab tantangan yang terjadi dalam abad ke-21. Pada abad ke-21 ini, pendidikan memiliki peranan penting dalam pem bentukan karakter dan moral bangsa Indonesia. Pen didikan berfungsi untuk mempersiapkan dan melahir kan sumber daya manusia (SDM) yang berkualitas dalam rangka mencerdaskan kehidupan bangsa. Pemerintah telah berupaya menjawab tantangan tersebut dengan melakukan peningkatan kualitas pendidikan Indonesia. Untuk meningkatkan kualitas pendidikan, pemerintah senantiasa berupaya dalam memperbaiki mutu pendidikan Indonesia. Salah satu upaya pemerintah adalah melakukan perubahan Kurikulum Tingkat Satuan Pendidikan (KTSP) menjadi Kurikulum 2013.

Pendekatan saintifik dalam Kurikulum 2013 dirancang agar siswa dapat aktif dalam pembelajaran dengan tahapan yaitu mengamati, merumuskan hipo tesis, mengumpulkan data, menganalisis data, dan me narik kesimpulan yang dapat membantu siswa ${ }^{[2]}$. 
Kurikulum 2013 merupakan penyempurnaan dari KTSP dan dikembangkan atas dasar perbaikan kuri kulum sebelumnya. Proses pembelajaran pada kuri kulum 2013 dilaksanakan menggunakan pendekatan saintifik mencakup tiga aspek, yaitu sikap, pengetahu an, dan keterampilan. Adapun tujuan dari perubahan kurikulum tersebut adalah agar mampu menciptakan kondisi belajar siswa yang aktif, kreatif, inovatif, dan berkarakter sebagaimana yang dicita-citakan. Salah satu mata pelajaran yang berperan penting dalam pengembangan potensi sumber daya manusia adalah mata pelajaran IPA.

Ilmu Pengetahuan Alam (IPA) merupakan ilmu pengetahuan yang sistematis dan menyeluruh. IPA dipandang sebagai cara berpikir untuk memahami alam, melakukan penyelidikan, dan sebagai kumpul an pengetahuan ${ }^{[3]}$. IPA merupakan salah satu jenis pendidikan yang membahas tentang fenomena alam secara sistematis ${ }^{[4]}$. Jadi, dapat disimpulkan bahwa IPA adalah ilmu pengetahuan yang membahas feno mena alam secara menyeluruh.

IPA bukan hanya kumpulan berupa fakta, konsep, dan prinsip, melainkan suatu proses penemu an dan pengembangan. Pendidikan IPA diarahkan untuk proses penemuan dan berbuat sehingga dapat membantu siswa agar memperoleh pemahaman yang lebih mendalam tentang alam sekitar. Oleh karena itu, IPA merupakan pembelajaran penting untuk di ajarkan kepada siswa.

Pada Kurikulum 2013, pembelajaran IPA di laksanakan secara terpadu. Mata pelajaran IPA di SMP dilakukan dengan konsep IPA terpadu ${ }^{[3]}$, Konsep keterpaduan ini ditujukan pada penyajian materi IPA yang dikemas ke dalam tema tertentu yang didalamnya membahas materi Fisika, Biologi, dan Kimia yang memiliki keterkaitan. Materi Fisika, Biologi, dan Kimia tidak lagi diajarkan oleh masingmasing guru, melainkan dijadikan satu kesatuan bidang kajian yang tidak dapat dipisahkan. Pem belajaran IPA diharapkan tidak hanya memberikan konsep materi saja, tetapi memberikan makna yang dapat diambil dalam proses pembelajaran.

Pembelajaran IPA Terpadu bertujuan untuk meningkatkan efisiensi dan efektivitas pembelajaran, dan beberapa kompetensi dasar akan dicapai se kaligus $^{[5]}$. Pembelajaran IPA Terpadu terdiri dari sepuluh tipe keterpaduan ${ }^{[6]}$. Tipe pembelajaran yang sering digunakan dalam pembelajaran adalah tipe terjaring. Tipe terjaring adalah tipe yang mengguna kan tema dalam proses pembelajaran. Hal ini di karenakan tipe terjaring sesuai digunakan pada pembelajaran IPA Terpadu.

Pemerintah juga berupaya meningkatkan literasi siswa melalui program Gerakan Literasi Sekolah (GLS). GLS merupakan sebuah upaya yang dilaku kan secara menyeluruh untuk menjadikan sekolah sebagai organisasi pembelajaran yang mampu meng akses, memahami, dan digunakan melalui berbagai aktivitas, seperti membaca, menulis, dan men yimak $^{[7]}$. GLS bertujuan untuk menumbuhkan budi pekerti siswa dengan adanya kegiatan membaca yang efektif. Adapun tahapan dalam pelaksanaan GLS adalah pembiasaan melalui kegiatan 15 menit membaca, pengembangan melalui kegiatan mengasah kemampuan untuk menanggapi bacaan, dan pem belajaran melalui kegiatan mengembangkan ke mampuan memahami bacaan.

Kenyataan yang ditemukan di lapangan belum sesuai dengan kondisi yang diharapkan. Hal ini diketahui melalui studi pendahuluan yang sudah dilakukan untuk dapat mengetahui masalah dalam penelitian. Studi pendahuluan ini dilakukan di SMPN 8 Padang mencakup pelaksanaan pembelajaran IPA Terpadu, LKS yang digunakan dalam pembelajaran, literasi siswa, dan hasil belajar siswa.

Kenyataan pertama didapatkan dari pelaksanaan pembelajaran IPA di sekolah. Hasil wawancara, me nunjukkan bahwa pembelajaran IPA sudah dilaksana kan secara terpadu, tetapi pelaksanaan pembelajaran masih belum maksimal. Kenyataan kedua didapatkan dari hasil analisis LKS. Hasil analisis LKS yang di lakukan pada empat jenis LKS MGMP IPA adalah tingkat keterpaduan LKS IPA berada pada kategori rendah. Kenyataan ketiga didapatkan dari analisis literasi siswa. Hasil analisis literasi siswa kelas VIII SMPN 8 Padang adalah 49,78. Hasil ini menunjuk kan bahwa literasi siswa kelas VIII SMPN 8 Padang masih tergolong rendah. Kenyataan terakhir di ketahui dari hasil belajar siswa. Hasil belajar siswa kelas VIII SMPN 8 Padang menunjukkan bahwa rata-rata UAS siswa secara keseruluhan tahun ajaran 2016/2017 yaitu 65,32.

Berdasarkan kondisi nyata yang ditemukan belum sesuai dengan kondisi ideal yang diharapkan. Pada kondisi nyata pelaksanaan IPA Terpadu belum dilaksanakan dengan optimal, LKS IPA yang digunakan masih belum terdapat keterpaduan materi, literasi siswa masih tergolong rendah, dan hasil belajar siswa pada pelajaran IPA masih belum sesuai harapan. Pelaksanaan pembelajaran IPA Terpadu di sekolah sebaiknya juga diiringi dengan penggunaan bahan ajar yang terpadu. Salah satu bentuk bahan ajar adalah LKS. LKS adalah panduan siswa yang digunakan untuk melakukan kegiatan penyelidikan atau pemecahan masalah ${ }^{[3]}$. Struktur LKS yang baik dan benar meliputi judul /identitas, petunjuk belajar, kompetensi yang akan dicapai, informasi pendukung, tugas-tugas dan langkah kerja, serta penilaian ${ }^{[5]}$. Penggunaan LKS dapat meningkatkan keaktifan dan kemampuan siswa untuk berpikir.

Solusi dalam mengatasi masalah ini adalah menggunakan LKS IPA Terpadu bermuatan ke terampilan literasi tema gerak dalam kehidupan. LKS yang digunakan adalah LKS IPA Terpadu tema gerak dalam kehidupan yang telah di teliti oleh Esti. LKS ini telah melakukan uji validitas dan praktikalitas dengan nilai rata-rata validitas oleh tenaga kerja sebesar 84.8 , sedangkan nilai rata-rata prakti kalitas 
oleh guru sebesar 90.3, dan nilai rata-rata prakti kalitas oleh siswa adalah $90.3^{[8]}$. LKS IPA Terpadu tema gerak dalam kehidupan ini dipilih karena memiliki keterpaduan pada materi IPA secara keseluruhan dan dapat membantu dalam proses pembelajaran sehingga dapat meningkatkan kompe tensi siswa. LKS IPA Terpadu bermuatan keterampil an literasi mencakup literasi era digital yang meliputi literasi fungsional, saintifik, dan visual. Literasi era digital adalah kemampuan pemahaman siswa mencakup membaca, menulis, dan menghitung. Literasi era digital dibedakan atas tujuh bagian ${ }^{[9]}$. Literasi era digital pada penelitian ini mencakup literasi fungsional meliputi menulis, men deskripsikan informasi, menggambar, menghitung, literasi saintifik meliputi konsep, proses, konteks saintifik, dan literasi visual meliputi memanfaatkan dan menafsirkan gambar.

Penelitian yang relevan terkait penelitian ini yaitu Putri ${ }^{[10]}$, Ayu ${ }^{[11]}$, Esti ${ }^{[8]}$, dan $\mathrm{Ika}^{[12]}$. Ada empat perbedaan penelitian ini dengan penelitian yang relevan. Pertama, LKS yang digunakan pada peneliti an ini menerapkan pembelajaran yang bersifat tema tik sehingga pembelajaran dapat terlaksana dengan maksimal. Kedua, LKS yang digunakan adalah LKS berintegrasi keterampilan literasi yang disesuaikan dengan perkembangan IPTEK abad ke-21. Ketiga, LKS yang digunakan menerapkan pembelajaran yang bersifat kontekstual. Keempat, model pembelajaran yang digunakan adalah model pembelajaran konteks tual, sehingga dapat membantu siswa untuk me mahami materi pembelajaran.

Tujuan penelitian ini adalah untuk menentukan pengaruh penggunaan LKS IPA Terpadu bermuatan keterampilan literasi tema gerak dalam kehidupan terhadap kompetensi siswa kelas VIII SMPN 8 Padang. Disisi lain, hipotesis kerja pada penelitian ini adalah terdapat hubungan yang berarti antara kompetensi siswa dengan penggunaan LKS IPA Terpadu bermuatan keterampilan literasi tema gerak dalam kehidupan kelas VIII SMPN 8 Padang.

\section{METODE PENELITIAN}

Jenis penelitian yang akan dilakukan sesuai dengan permasalahan dan tujuan yang ingin dicapai adalah eksperimen semu. Desain penelitian yang di gunakan adalah tes awal dan tes akhir satu kelompok. Tabel 1. Jenis Penelitian Tes Awal dan Tes Akhir Satu Kelompok ${ }^{[13]}$

\begin{tabular}{|c|c|c|}
\hline Tes Awal & Prelakuan & Tes Akhir \\
\hline $\mathrm{O}_{1}$ & $\mathrm{X}$ & $\mathrm{O}_{2}$ \\
\hline
\end{tabular}

Keterangan:

$\mathrm{O}_{1}=$ Nilai tes awal (sebelum diberi perlakuan)

$\mathrm{X}=$ Perlakuan yang diberikan pada kelas eksperimen yaitu pembelajaran meng gunakan LKS IPA Terpadu bermuatan keterampilan literasi.

$\mathrm{O}_{2}=$ Nilai tes akhir (sebelum diberi perlakuan)
Variabel penelitian terdiri dari variabel bebas dan variabel terikat. Variabel bebas dalam penelitian ini adalah LKS IPA Terpadu bermuatan keterampilan literasi tema gerak dalam kehidupan. Variabel terikat dalam penelitian ini adalah kompetensi siswa kelas VIII SMPN 8 Padang.

Pengambilan sampel pada penelitian ini meng gunakan teknik sampel bertujuan. Sampel bertujuan adalah teknik pengambilan sampel dengan per timbangan tertentu ${ }^{[13]}$. Penelitian ini dilaksanakan di satu kelas yang pembelajarannya menggunakan LKS IPA Terpadu bermuatan keterampilan literasi tema gerak dalam kehidupan dan menerapkan model pembelajaran kontekstual adaptif yaitu kelas VIII B SMPN 8 Padang.

Prosedur pada penelitian ini meliputi tiga tahap yaitu persiapan, pelaksanaan, dan penyelesaian. Permasalahan yang muncul dalam penelitian adalah pelaksanaan pembelajaran IPA Terpadu masih belum optimal, literasi dalam pembelajaran masih tergolong rendah. Hal ini digambarkan dari studi awal yang telah dilakukan.

Instrumen pengumpulan data pada penelitian ini terdiri dari tiga bagian yaitu instrumen kompetensi sikap, kompetensi pengetahuan dan kompetensi keterampilan. Instrumen yang digunakan untuk mengetahui kompetensi sikap siswa adalah lembar observasi, kompetensi pengetahuan adalah tes tertulis yang dilakukan pada awal dan akhir penelitian serta tugas pengetahuan dalam LKS IPA Terpadu bermuatan keterampilan literasi tema gerak dalam kehidupan, kompetensi keterampilan adalah keterampilan dalam LKS IPA Terpadu bermuatan keterampilan literasi tema gerak dalam kehidupan dan penilaian kinerja siswa.

Teknik analisis data yang digunakan adalah analisis statistik desktriptif, model regresi linear sederhana, uji hubungan dua variabel, uji hipotesis menggunakan uji t dan uji t berkorelasi, uji besar pengaruh variabel. Analisis model regresi linear sederhana dilakukan menggunakan statistik deskriptif yang digambarkan melalui diagram. Uji hubungan dua variabel untuk mengetahui seberapa kuat hubungan antara dua variabel ${ }^{[11]}$. Rumus hubungan dua variabel yaitu:

$$
r_{x y}=\frac{n \sum x i y i-\left(\sum x i\right)\left(\sum y i\right)}{\sqrt{\left(n \sum x i^{2}-(x i)^{2}\left(n \sum y i^{2}-(y i)^{2}\right)\right)}}
$$

Selanjutnya setelah mendapatkan hasil uji hubungan dua variabel dilakukan uji hipotesis. Untuk menguji hipotesis pada kompetensi pengetahuan dan ke terampilan dapat menggunakan rumus uji $\mathrm{t}^{[13]}$. Uji $\mathrm{t}$ bertujuan untuk menguji hubungan dua variabel Rumus uji t yaitu :

$$
t=\frac{r \sqrt{n-2}}{\sqrt{1-r^{2}}}
$$

Keterangan:

$r$ = Hubungan dua variabel

$\mathrm{n}=$ Jumlah sampel 
Untuk uji hipotesis pada kompetensi sikap dan tes awal dan tes akhir menggunakan rumus t-test berkolerasi ${ }^{[10]}$. Uji $t$ berkorelasi bertujuan untuk menguji hipotesis komparatif dua sampel yang berkorelasi. Rumus uji t-test berkorelasi yaitu:

$$
t=\frac{\overline{X_{1}}-\overline{X_{2}}}{\sqrt{\frac{s_{1}^{2}}{n_{1}}+\frac{s_{2}^{2}}{n_{2}}-2 r\left(\frac{s_{1}}{\sqrt{n_{1}}}\right)\left(\frac{s_{2}}{\sqrt{n_{2}}}\right)}}
$$

Keterangan:

$$
\begin{aligned}
& \overline{X_{1}}=\text { Rata-rata awal } \\
& \overline{X_{2}}=\text { Rata-rata akhir } \\
& S_{1}=\text { Simpangan baku awal } \\
& S_{2}=\text { Simpangan baku akhir } \\
& S_{1}^{2}=\text { Varians awal } \\
& S_{2}^{2}=\text { Varians akhir } \\
& \mathrm{r}=\text { Hubungan dua variabel }
\end{aligned}
$$

$\mathrm{H}_{0}$ ditolak jika $\mathrm{t}_{\mathrm{h}}<\mathrm{t}_{\mathrm{t}}$. pada taraf nyata 0,05 dan $\mathrm{dk}$ $\left(n_{1}+n_{2}-2\right)$ dengan uji pihak kiri. Jika harga $t_{h}$ kecil dari $t_{t}$, maka dapat dapat dikatakan bahwa terdapat pengaruh yang berarti antara penggunaan LKS IPA Terpadu bermuatan keterampilan literasi tema gerak dalam kehidupan terhadap kompetensi siswa.

\section{HASIL PENELITIAN DAN PEMBAHASAN 1. Hasil Penelitian}

Hasil penelitian pertama adalah pengaruh LKS IPA Terpadu bermuatan keterampilan literasi tema gerak dalam kehidupan terhadap kompetensi sikap. Hasil penelitian pada kompetensi sikap diambil dengan menggunakan lembar observasi dan dibantu oleh seorang observer. Penilaian kompetensi sikap yang dinilai meliputi enam aspek penilaian yaitu sikap ingin tahu, percaya diri, disiplin, komitmen inkuiri, kerjasama, dan komunikatif. Deskripsi data kompetensi sikap ini ditunjukkan dari skor total yang diperoleh siswa untuk tiap indikator sikap selama 4 kali perlakuan di kelas dapat dilihat pada Tabel 2.

Tabel 2. Deskripsi Data Kompetensi Sikap Awal dan Akhir Siswa

\begin{tabular}{|l|c|c|c|c|c|c|c|}
\hline Penilaian & N & IT & PD & D & KI & KS & KM \\
\hline Awal & 32 & 69,5 & 76,2 & 64,8 & 78,1 & 83,6 & 78,9 \\
\hline Akhir & 32 & 83,6 & 82,6 & 73,2 & 80,1 & 85,0 & 84,8 \\
\hline
\end{tabular}

Berdasarkan deskripsi data pada Tabel 2 dapat dilihat bahwa data kompetensi sikap mengalami peningkatan, artinya kompetensi sikap siswa me ningkat setelah menggunakan LKS IPA Terpadu ber muatan keterampilan literasi. Data penelitian kompe tensi sikap siswa yang telah didapatkan selanjutnya di analisis menggunakan uji t berkorelasi. Analisis dilakukan untuk melihat apakah terdapat pengaruh yang berarti antara penggunaan LKS IPA Terpadu bermuatan keterampilan literasi tema gerak dalam kehidupan siswa terhadap kompetensi sikap siswa. Analisis data yang dilakukan adalah pertama, uji normalitas. Uji normalitas ini bertujuan untuk mengetahui apakah data sampel terdistribusi normal. Hasil uji normalitas kompetensi sikap awal dan akhir sikap dapat dilihat pada Tabel 3.

Tabel 3. Hasil Uji Normalitas Kompetensi Sikap Siswa

\begin{tabular}{|l|c|c|c|c|c|}
\hline \multicolumn{1}{|c|}{ Penilaian } & $\mathrm{N}$ & $\alpha$ & Lo & Lt & Keterangan \\
\hline Sikap Awal & 32 & \multirow{2}{*}{0.05} & 0,07 & 0,156 & Normal \\
\cline { 1 - 2 } \cline { 4 - 7 } Sikap Akhir & 32 & & 0,06 & 0,156 & Normal \\
\hline
\end{tabular}

Berdasarkan hasil uji normalitas pada Tabel 3 memperlihatkan bahwa sikap awal dan akhir mempunyai harga $\mathrm{L}_{\mathrm{o}}<\mathrm{L}_{\mathrm{t}}$ pada taraf nyata 0,05 , berarti data kompetensi sikap awal dan akhir siswa ter distribusi normal. Kedua, uji hubungan dua variabel. Hasil uji hubungan dua variabel pada kompetensi sikap siswa diperoleh 0,95. Ketiga, Uji Hipotesis. Hasil uji hipotesis diperoleh nilai $t_{h}$ adalah $-6,26$, sedangkan $t_{t}$ adalah -2,00 dengan uji pihak kiri. Hipotesis nol ditolak jika $t_{h}<t_{t}$. Berdasarkan analisis data dapat disimpulkan bahwa hipotesis nol ditolak, artinya terdapat pengaruh yang berarti antara LKS IPA Terpadu bermuatan keterampilan literasi tema gerak dalam kehidupan terhadap kompetensi sikap siswa kelas VIII SMPN 8 Padang.

Hasil penelitian kedua adalah pengaruh LKS IPA Terpadu bermuatan keterampilan literasi tema gerak dalam kehidupan terhadap kompetensi pengetahuan siswa. Hasil penelitian pada kompetensi pengetahuan IPA Terpadu. Data penelitian ini di peroleh dari tes awal, tes akhir dan tugas pengetahu an dalam LKS IPA Terpadu bermuatan keterampilan literasi tema gerak dalam kehidupan. Data penelitian pada kompetensi pengetahuan terdiri dari dua yaitu: Pertama, pengaruh LKS IPA Terpadu bermuatan keterampilan literasi terhadap pengetahuan. Hasil penelitian pada pengetahuan di peroleh dari tes awal dan tes akhir. Deskripsi data pengetahuan tes awal dan tes akhir dapat dilihat pada Tabel 4.

Tabel 4. Deskripsi Data Tes Awal dan Tes Akhir Pengetahuan

\begin{tabular}{|c|c|c|c|c|c|c|}
\hline Penilaian & N & $\begin{array}{c}\text { Nilai } \\
\text { Tertinggi }\end{array}$ & $\begin{array}{c}\text { Nilai } \\
\text { Terendah }\end{array}$ & $\bar{X}$ & $\mathbf{S}^{2}$ & $\mathrm{~S}$ \\
\hline Tes awal & 32 & 56 & 32 & 45,63 & 41,09 & 6,41 \\
\hline Tes Akhir & 32 & 95 & 70 & 82,50 & 39,06 & 6,25 \\
\hline
\end{tabular}

Berdasarkan deskripsi data pada Tabel 4 menyatakan bahwa pengetahuan awal dan akhir mengalami peningkatan. Data penelitian pengetahuan siswa yang telah didapatkan selanjutnya di analisis menggunakan uji t berkorelasi. Analisis di lakukan untuk melihat apakah terdapat pengaruh yang berarti antara pada penggunaan LKS IPA Terpadu ber muatan keterampilan literasi siswa terhadap penge tahuan siswa. Analisis data yang di lakukan pada penelitian ada tiga tahap yaitu uji normalitas. Hasil uji normalitas dapat dilihat pada Tabel 5.

Tabel 5. Uji Normalitas Pengetahuan Tes Awal dan Tes Akhir Siswa

\begin{tabular}{|l|c|c|c|c|c|}
\hline \multicolumn{1}{|c|}{ Penilaian } & $\mathrm{N}$ & $\alpha$ & Lo & Lt & Keterangan \\
\hline Tes awal & 32 & \multirow{2}{*}{0,05} & 0,106 & 0,156 & Normal \\
\cline { 1 - 4 } \cline { 5 - 7 } & 32 & & 0,095 & 0,156 & Normal \\
\hline
\end{tabular}

Pada Tabel 5 menyatakan bahwa data penelitian pada pengetahuan terdistribusi normal. Setelah uji normalitas, dilakukan uji hubung an dua variabel. Harga $r$ pada uji korelasi sebesar 0,143. Uji Hipotesis dilakukan setelah uji hubungan dua variabel. Hasil uji hipotesis menyatakan bahwa diperoleh nilai $t_{h}$ adalah $-24,89$, sedangkan $t_{t}$ adalah 
$-2,00$ dengan uji pihak kiri. Hipotesis nol ditolak jika $t_{h}<t_{t}$. Berdasarkan data tersebut dapat disimpulkan bahwa hipotesis nol ditolak, artinya terdapat pengaruh yang berarti antara penggunaan LKS IPA Terpadu bermuatan keterampilan literasi tema gerak dalam kehidupan terhadap pengetahuan siswa kelas VIII SMPN 8 Padang. Kedua, pengaruh tugas penge tahuan dalam LKS IPA Terpadu bermuatan keterampilan literasi tema gerak dalam kehidupan terhadap kompetensi pengetahuan. Deskripsi data kompetensi pengetahuan LKS IPA Terpadu bermuatan keterampilan literasi tema gerak dalam kehidupan dan tes akhir dapat dilihat pada Tabel 6.

Tabel 6. Deskripsi Data Tugas Pengetahuan dalam LKS IPA Terpadu dan Tes Akhir

\begin{tabular}{|l|c|c|c|c|c|c|}
\hline Penilaian & $\mathrm{N}$ & $\begin{array}{c}\text { Nilai } \\
\text { Tertinggi }\end{array}$ & $\begin{array}{c}\text { Nilai } \\
\text { Terendah }\end{array}$ & $\bar{X}$ & $\mathbf{S}^{\mathbf{2}}$ & $\mathrm{S}$ \\
\hline $\begin{array}{l}\text { Tugas } \\
\text { LKS }\end{array}$ & 32 & 96,7 & 68,1 & 83,29 & 63,52 & 7,97 \\
\hline Tes Akhir & 32 & 95,0 & 70,0 & 82,50 & 39,06 & 6,25 \\
\hline
\end{tabular}

Berdasarkan Tabel 6 menyatakan bahwa selisih rata-rata tugas pengetahuan dalam LKS IPA Terpadu bermuatan keterampilan literasi tema gerak dalam kehidupan dan tes akhir yaitu 1,09. Nilai simpangan baku tugas pengetahuan dalam LKS IPA Terpadu bermuatan keterampilan literasi lebih besar dibanding kan tes akhir. Analisis data yang dilakukan pada penelitian ini adalah uji normalitas, uji normalitas bertujuan untuk mengetahui apakah data pada sampel terdistribusi normal. Hasil uji normalitas kompetensi pengetahuan dapat dilihat pada Tabel 7.

Tabel 7. Hasil Uji Normalitas Tugas dalam LKS IPA Terpadu dan Tes Akhir

\begin{tabular}{|l|c|c|c|c|c|}
\hline \multicolumn{1}{|c|}{ Penilaian } & $\mathrm{N}$ & $\alpha$ & Lo & Lt & Keterangan \\
\hline $\begin{array}{l}\text { Tugas dalam LKS } \\
\text { IPA Terpadu }\end{array}$ & 32 & \multirow{2}{*}{0.05} & 0,116 & 0,156 & Normal \\
\cline { 1 - 3 } \cline { 5 - 6 } Tes Akhir & 32 & & 0,095 & 0,156 & Normal \\
\hline
\end{tabular}

Berdasarkan Tabel 7 menunjukkan bahwa hasil uji normalitas pada tugas pengetahuan dalam LKS IPA Terpadu bermuatan keterampilan literasi tema gerak dalam kehidupan dan penilaian kinerja terdistribusi normal. Kemudian dilakukan uji regresi linear sederhana. Persamaan regresi linear sederhana diperoleh dari hubungan variabel bebas dengan variabel terikat. Bentuk sebaran model regresi linear sederhana pada tugas pengetahuan dalam LKS IPA Terpadu dengan kompetensi pengetahuan siswa dapat dilihat pada Gambar 1 .

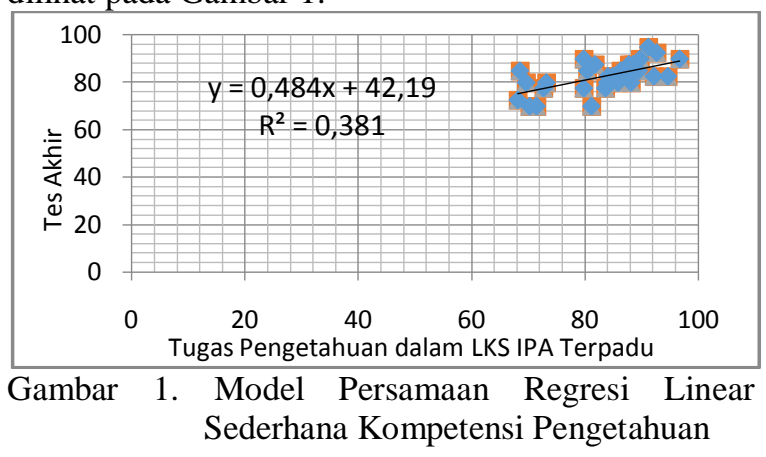

Pada Gambar 1 didapatkan diagram pencar yang dibentuk dari nilai $\mathrm{X}$ yaitu tugas pengetahuan dalam LKS IPA Terpadu bermuatan keterampilan literasi tema gerak dalam kehidupan dan nilai Y yaitu hasil belajar kompetensi pengetahuan siswa. Berdasarkan diagram pencar tersebut didapatkan bahwa hubungan antara variabel bebas dengan variabel terikat adalah linear. Model regresi linear sederhana yang diperoleh dari tes akhir dan nilai tugas pengetahuan LKS IPA Terpadu bermuatan keterampilan literasi tema gerak dalam kehidupan adalah sebagai berikut:

$$
\widehat{Y_{1}}=42,19+0,48 X
$$

Setelah mendapatkan persamaan regresi linear sederhana, dilakukan uji keberartian dan uji lineari tas. Hasil uji keberartian dan uji linearitas dapat dilihat pada Tabel 8.

Tabel 8. Analisis Varians Regresi Linear Sederhana

\begin{tabular}{|c|c|c|c|c|}
\hline Sumber Variansi & $\mathrm{dk}$ & $\mathrm{JK}$ & KT & $\mathrm{F}$ \\
\hline Total & 32 & 219012,5 & 219012,5 & \\
\hline Koefisien (a) & 1 & 217800 & 217800 & \\
\hline Regresi (b/a) & 1 & 458,904 & 458,904 & \multirow{2}{*}{$\begin{aligned} \mathrm{Fh} & =18,27 \\
\mathrm{Ft} & =4,17 \\
\mathrm{Fh} & >\mathrm{Ft}\end{aligned}$} \\
\hline Sisa & 30 & 753,6 & 25,12 & \\
\hline Tuna Cocok & 27 & 669,22 & 24,79 & \multirow{2}{*}{$\begin{array}{c}\mathrm{Fh}=0,88 \\
\mathrm{Ft}=8,64 \\
\mathrm{Fh}<\mathrm{Ft}\end{array}$} \\
\hline Galat & 3 & 84,38 & 28,13 & \\
\hline
\end{tabular}

Berdasarkan Tabel 8 terlihat bahwa hasil uji keberartian diperoleh nilai $F_{h}$ adalah 18,27, sedangkan nilai $F_{t}$ adalah 4,17. Syarat uji keberartian adalah $\mathrm{F}_{\mathrm{h}}>\mathrm{F}_{\mathrm{t}}$. Kesimpulan koefisien arah regresi tersebut berarti. Untuk hasil uji linearitas diperoleh $F_{h}$ adalah 0,88 . Disisi lain nilai $F_{t}$ adalah 8,64. Syarat uji linearitas adalah $F_{h}<F_{t}$. Kesimpulan data tersebut regresi linear. Hubungan regresi linear sederhana antara tugas pengetahuan dalam LKS IPA Terpadu bermuatan keterampilan literasi tema gerak dalam kehidupan terhadap kompetensi keterampilan adalah berarti. Uji hubungan dua variabel dilakukan setelah melakukan analisis regresi linear sederhana. Hasil uji korelasi didapatkan bahwa nilai $\mathrm{r}$ sebesar 0,62. Berdasarkan hasil korelasi maka dapat dinyatakan bahwa keeratan hubungan antara penggunaan LKS IPA Terpadu bermuatan keterampilan literasi tema gerak dalam kehidupan terhadap kompetensi siswa adalah kuat.

Selanjutnya melakukan uji hipotesis untuk mengetahui hubungan variabel. Hasil analisis data dapat dijelaskan bahwa hipotesis nol ditolak, sehingga terdapat hubungan yang berarti antara kompetensi pengetahuan siswa dengan tugas pengetahuan dalam LKS IPA Terpadu bermuatan keterampilan literasi tema gerak dalam kehidupan. Terakhir dilakukan uji penentuan besar pengaruh variabel bebas. Berdasar kan hasil uji hipotesis dapat disimpulkan bahwa LKS IPA Terpadu bermuatan keterampilan literasi tema gerak dalam kehidupan memberikan kontribusi terhadap kompetensi pengetahuan siswa sebesar 38,44\% dan 61,56\% dipengaruhi oleh variabel lain.

Hasil penelitian ketiga adalah pengaruh LKS 
IPA Terpadu bermuatan keterampilan literasi tema gerak dalam kehidupan terhadap kompetensi ke terampilan. Hasil penelitian pada kompetensi ke terampilan diperoleh dari keterampilan siswa dalam LKS IPA Terpadu bermuatan keterampilan literasi tema gerak dalam kehidupan dan penilaian kinerja yang diperoleh melalui hasil pengamatan selama kegiatan eksperimen berlangsung dan laporan hasil kegiatan eksperimen. Penilaian dilakukan sebanyak empat per lakuan berdasarkan indikator masingmasing aspek yang dinilai sesuai rubrik penskoran kompetensi keterampilan. Deskripsi data kompetensi keterampilan dalam LKS IPA Terpadu bermuatan keterampilan literasi tema gerak dalam kehidupan dan penilaian kinerja siswa kelas VIII dapat dilihat pada Tabel 9.

Tabel 9. Data Kompetensi Keterampilan dalam LKS IPA Terpadu dan Penilaian Kinerja

\begin{tabular}{|l|c|c|c|c|c|c|}
\hline \multicolumn{1}{|c|}{ Penilaian } & $\mathrm{N}$ & $\begin{array}{c}\text { Nilai } \\
\text { Tertinggi }\end{array}$ & $\begin{array}{c}\text { Nilai } \\
\text { Terendah }\end{array}$ & $\bar{X}$ & $\mathbf{S}^{\mathbf{2}}$ & $\mathrm{S}$ \\
\hline $\begin{array}{l}\text { Keterampilan } \\
\text { dalam LKS } \\
\text { IPA Terpadu }\end{array}$ & 32 & 98,5 & 74,0 & 87,85 & 58,52 & 7,65 \\
\hline Kinerja & 32 & 98,4 & $71 ., 1$ & 86,72 & 59,44 & 7,71 \\
\hline
\end{tabular}

Berdasarkan deskripsi data pada Tabel 9 bahwa nilai selisih rata-rata kompetensi keterampilan dalam LKS IPA Terpadu bermuatan keterampilan literasi tema gerak dalam kehidupan dengan pe nilaian kinerja siswa adalah 1,13 . Data penelitian kompetensi keterampilan siswa yang telah didapatkan selanjutnya dianalisis menggunakan uji t. Analisis data dilakukan untuk melihat apakah terdapat hubungan yang berarti antara keterampilan dalam LKS IPA Terpadu bermuatan keterampilan literasi terhadap kompetensi keterampilan siswa. Analisis data yang dilakukan adalah pertama, Uji normalitas. Uji normalitas bertujuan untuk menge tahui apakah data pada sampel terdistribusi normal. Hasil uji normalitas keterampilan dalam LKS IPA Terpadu bermuatan keterampilan literasi tema gerak dalam kehidupan dan penilaian kinerja siswa dapat dilihat pada Tabel 10.

Tabel 10. Uji Normalitas Keterampilan dalam LKS IPA Terpadu dan Penilaian Kinerja

\begin{tabular}{|l|c|c|c|c|c|}
\hline \multicolumn{1}{|c|}{ Penilaian } & $\mathrm{N}$ & $\alpha$ & Lo & Lt & Keterangan \\
\hline $\begin{array}{l}\text { Keterampilan dalam } \\
\text { LKS IPA Terpadu }\end{array}$ & 32 & $0 ., 05$ & 0,103 & $0 ., 156$ & Normal \\
\hline Kinerja & 32 & & 0,09 & 0,156 & Normal \\
\cline { 1 - 3 }
\end{tabular}

Berdasarkan Tabel 10 menunjukkan bahwa hasil uji normalitas data kompetensi keterampilan dalam LKS IPA Terpadu bermuatan keterampilan literasi tema gerak dalam kehidupan dan penilaian kinerja siswa terdistribusi normal. Kedua, Uji regresi linear sederhana. Persamaan regresi linear sederhana diperoleh dari hubungan variabel bebas dengan variabel terikat. Berdasarkan bentuk sebaran model regresi linear sederhana pada keterampilan dalam LKS IPA Terpadu bermuatan keterampilan literasi tema gerak dalam kehidupan dengan kompetensi keterampilan siswa kelas VIII di SMPN 8 Padang dapat dilihat pada Gambar 2.

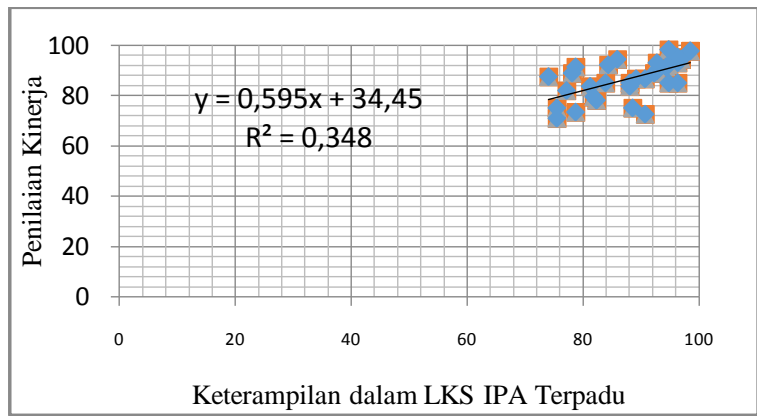

Gambar 2. Model Persamaan Regresi Linear Sederhana Kompetensi Keterampilan

Pada Gambar 2 didapatkan diagram pencar yang dibentuk dari nilai $\mathrm{X}$ yaitu keterampilan dalam LKS IPA Terpadu bermuatan keterampilan literasi tema gerak dalam kehidupan dan nilai Y yaitu hasil belajar pada kompetensi keterampilan siswa. Berdasarkan diagram pencar tersebut didapatkan bahwa hubungan antara variabel bebas dengan variabel terikat adalah linear. Model regresi linear sederhana yang diperoleh untuk hasil belajar siswa pada kompetensi keterampilan dan keterampilan dalam LKS IPA Terpadu bermuatan keterampilan literasi tema gerak dalam kehidupan adalah:

$$
\widehat{\mathrm{Y}}=34,35+0,595 \mathrm{X}
$$

Ketiga, uji keberartian dan uji linearitas. Hasil uji keberartian dan uji linearitas yang dapat dilihat pada Tabel 11 .

Tabel 11. Analisis Varians Regresi Linear Sederhana

\begin{tabular}{|c|c|c|c|c|}
\hline $\begin{array}{l}\text { Sumber } \\
\text { Variansi } \\
\end{array}$ & $\mathrm{Dk}$ & $\mathrm{JK}$ & KT & $\mathrm{F}$ \\
\hline Total & 32 & 242487,8 & 242487,8 & \\
\hline Koefisien (a) & 1 & 240644,53 & 240644,53 & \\
\hline Regresi (b/a) & 1 & 644,07 & 644,07 & \multirow{2}{*}{$\begin{array}{c}\mathrm{Fh}=16,114 \\
\mathrm{Ft}=4,17 \\
\mathrm{Fh}>\mathrm{Ft}\end{array}$} \\
\hline Sisa & 30 & 1199,2 & 39,97 & \\
\hline Tuna Cocok & 26 & 967,62 & 37,22 & \multirow{2}{*}{$\begin{array}{c}\mathrm{Fh}=0,64 \\
\mathrm{Ft}=5,77 \\
\mathrm{Fh}<\mathrm{Ft}\end{array}$} \\
\hline Galat & 4 & 231,58 & 57,89 & \\
\hline
\end{tabular}

Hasil uji keberartian diperoleh nilai $F_{h}$ adalah 16,114 , sedangkan nilai $F_{t}$ adalah 4,17 . Syarat uji keberartian adalah $\mathrm{F}_{\mathrm{h}}>\mathrm{F}_{\mathrm{tl}}$. Kesimpulan koefisien arah regresi tersebut berarti. Untuk uji linearitas diperoleh $\mathrm{F}_{\text {hitung }}$ adalah 0,64 , sedangkan nilai $\mathrm{F}_{\text {tabel }}$ adalah 5,77. Syarat uji linearitas adalah $\mathrm{F}_{\mathrm{h}}<\mathrm{F}_{\mathrm{t}}$. Kesimpulan data tersebut regresi linear. Hubungan regresi linear antara kompetensi keterampilan dengan keterampilan dalam LKS IPA Terpadu bermuatan keterampilan literasi tema gerak dalam kehidupan adalah berarti. Keempat, uji hubungan dua variabel. Hasil uji korelasi didapatkan bahwa nilai $r$ sebesar 0,59. Berdasarkan hasil korelasi, maka dapat dinyatakan bahwa keeratan hubungan antara penggunaan LKS IPA Terpadu bermuatan keterampilan literasi tema gerak dalam kehidupan dengan kompetensi ke terampilan siswa adalah sedang.

Kelima, uji Hipotesis. Hasil uji hipotesis diperoleh nilai $t_{h}$ adalah 4,02, sedangkan $t_{t}$ adalah 2,04. Hipotesis nol di terima jika $t_{h}<t_{t}$. Berdasarkan 
data tersebut dapat dikemukakan bahwa terdapat hubungan yang berarti antara kompetensi keterampil an siswa dengan penggunaan LKS IPA Terpadu bermuatan tema gerak dalam kehidupan dengan kompetensi keterampilan siswa. Keenam, uji pe nentuan besar pengaruh variabel bebas. Berdasarkan hasil uji penentuan besar pengaruh variabel bebas dapat disimpulkan bahwa LKS IPA Terpadu ber muatan keterampilan literasi tema gerak dalam kehidupan memberikan kontribusi ter hadap kompetensi keterampilan siswa sebesar 35,05\%.

\section{Pembahasan}

Hasil penelitian pada kompetensi sikap diperoleh dari rata-rata dari enam aspek yang dinilai. Hasil penelitian pada kompetensi sikap menunjukkan bahwa terdapat pengaruh yang berarti antara peng gunaan LKS IPA Terpadu bermuatan keterampilan literasi tema gerak dalam kehidupan dengan kompe tensi sikap siswa kelas VIII SMPN 8 Padang. Hal ini terlihat dari rata-rata sikap awal dan akhir mengguna kan LKS IPA Terpadu bermuatan keterampilan literasi yang menunjukkan keenam aspek tersebut mengalami peningkatan. Penggunaan LKS IPA Terpadu bermuatan keterampilan literasi tema gerak dalam kehidupan dapat meningkatkan kompetensi sikap siswa karena pembelajaran IPA Terpadu pada LKS IPA Terpadu bermuatan keterampilan literasi menerapkan model pembelajaran kontekstual adaptif yang menghubungkan materi pembelajaran dengan kondisi dunia nyata. Kompetensi sikap merupakan peran penting dalam menentukan arah pembelajaran untuk dapat meningkatkan kompetensi siswa ${ }^{[14]}$, sehingga pelaksanaan pembelajaran ini diharapkan mampu meningkatkan kompetensi sikap.

Hasil penelitian pada kompetensi pengetahuan terdiri atas dua yaitu pertama, pengaruh LKS IPA Terpadu bermuatan keterampilan literasi tema gerak dalam kehidupan terhadap pengetahuan siswa. Berdasarkan hasil uji t berkorelasi diperoleh bahwa terdapat pengaruh yang berarti antara penggunaan LKS IPA Terpadu bermuatan keterampilan literasi tema gerak dalam kehidupan terhadap pengetahuan siswa. Hasil analisis data tes awal dan tes akhir mem perlihatkan bahwa mengalami peningkatan dengan selisih rata-rata sebesar 36,88. Kedua, hasil pengaruh tugas pengetahuan dalam LKS IPA Terpadu ber muatan keterampilan literasi tema gerak dalam ke hidupan terhadap kompetensi pengetahuan diperoleh dari tugas pengetahuan dalam LKS IPA Terpadu bermuatan keterampilan literasi dan hasil tes akhir menunjukkan bahwa terdapat hubungan yang berarti antara penggunaan LKS IPA Terpadu bermuatan keterampilan literasi tema gerak dalam kehidupan terhadap kompetensi penge tahuan siswa. LKS IPA Terpadu bermuatan keterampilan literasi dapat meningkatkan kompetensi pengetahuan siswa karena LKS IPA Terpadu yang digunakan pada penelitian ini bermuatan keterampilan literasi yang membantu siswa untuk menerapkan literasi, sehingga dapat meningkatkan kemampuan siswa dalam memahami bacaan dan kompetensi pengetahuan ${ }^{[1]}$.

Hasil penelitian pada kompetensi keterampil an berupa keterampilan dalam LKS IPA Terpadu ber muatan keterampilan literasi tema gerak dalam kehidupan dan penilaian kinerja selama proses kegiat an eksperimen berlangsung. Hasil uji hipotesis me nunjukkan bahwa terdapat hubungan yang berarti antara penggunaan LKS IPA Terpadu bermuatan keterampilan literasi tema gerak dalam kehidupan terhadap kompetensi keterampilan siswa. Peng gunaan LKS IPA Terpadu bermuatan keterampilan literasi tema gerak dalam kehidupan dalam proses pembelajaran dapat meningkatkan kompetensi ke terampilan siswa karena LKS IPA Terpadu ber muatan keterampilan literasi temaa gerak dalam ke hidupan melatih siswa untuk meningkatkan ke terampilan siswa dalam pembelajaran. Kompetensi keterampilan siswa secara umum adalah kemampuan mengemukakan pendapat, membuat laporan, dan berkomunikasi ${ }^{[15]}$. Kompetensi keterampilan dapat membantu siswa memahami pengetahuan melalui penyelidikan yang telah dilakukan. LKS berfungsi untuk memaksimalkan pemahaman dalam upaya pembentukan kemampuan dasar sesuai indikator pencapaian hasil belajar yang harus ditempuh oleh siswa $^{[4]}$. Jadi, dengan adanya penggunaan LKS IPA Terpadu bermuatan keterampilan literasi tema gerak dalam kehidupan dapat mendukung proses pem belajaran dan meningkatkan pemahaman siswa.

Berdasarkan hasil analisis data dari ketiga kompetensi yaitu sikap, pengetahuan dan keterampil an. Hasil analisis tersebut menunjukkan bahwa terdapat hubungan yang berarti antara penggunaan LKS IPA Terpadu bermuatan keterampilan literasi tema gerak dalam kehidupan terhadap kompetensi siswa kelas VIII SMPN 8 Padang. Penggunaan LKS IPA Terpadu bermuatan keterampilan literasi tema gerak dalam kehidupan dapat meningkatkan kompetensi siswa karena pembelajaran LKS IPA Terpadu bermuatan keterampilan literasi tema gerak dalam kehidupan menerapkan model pembelajaran konteks tual adaptif. Model pembelajaran kontekstual adaptif adalah pembelajaran yang menghubungkan materi pembelajaran dengan kondisi dunia nyata, sehingga pembelajaran tersebut dapat memberikan makna dan meningkatkan kompetensi siswa ${ }^{[1]}$. Kelebihan dari penggunaan LKS IPA Terpadu bermuatan keterampilan literasi tema gerak dalam kehidupan adalah LKS IPA Terpadu menerapkan model kontesktual adaptif yang menghubungkan materi dengan kondisi dunia nyata yang dapat membantu guru dan siswa dalam proses pem belajaran. LKS IPA Terpadu yang digunakan pada penelitian ini menerapkan keterampilan literasi yang dapat membantu siswa untuk meningkatkan literasi dan memahami materi pembelajaran.

Penelitian yang dilakukan tidak terlepas dari keterbatasan yang dihadapi. Penjelasan tentang ke 
terbatasan yang terjadi selama penelitian diharapkan akan menjadi pengalaman dan dapat diperbaiki oleh peneliti lanjutan. Adapun keterbatasan pe laksanaan pembelajaran menggunakan LKS IPA Terpadu bermuatan keterampilan literasi tema gerak dalam kehidupan adalah:

Keterbatasan pertama adalah materi pem belajaran pada penelitian ini masih terbatas pada satu tema. Tema pada penelitian ini yaitu tema gerak dalam kehidupan kelas VIII SMP pada semester satu. Solusi dari keterbatasan ini diharapkan ada peneliti lainnya yang melanjutkan penelitian mengenai peng gunaan LKS IPA Tepadu bermuatan keterampilan literasi dengan tema yang lain.

Keterbatasan kedua adalah keterampilan literasi yang diintegrasikan ke dalam LKS IPA Terpadu baru mencakup tiga bagian yaitu literasi fungsional, saintifik, dan visual. Keterampilan literasi mencakup literasi era digital dibedakan atas tujuh bagian yaitu literasi dasar, saintifik, ekonomi, tekno logi, visual, informasi, multikultural, dan kesadaran global $^{[9]}$. Solusi untuk mengatasi keterbatasan ini adalah melanjutkan penelitian mengenai literasi era digital yang diintegrasikan ke dalam LKS IPA Terpadu pada bagian lainnya.

Ketiga, model pembelajaran pada penelitian ini masih menggunakan tipe terjaring. tipe terjaring adalah tipe yang menggunakan tema dalam pem belajaran dengan menyesuaikan pada situasi dan konteks $^{[4]}$. Solusi pada keterbatasan ini adalah diharapkan ada peneliti lain yang melanjutkan penelitian mengenai penggunaan tipe keterpaduan lainnya terkait pembelajaran IPA Terpadu, sehingga tipe yang dapat digunakan dalam pembelajaran IPA Terpadu bervariasi.

\section{KESIMPULAN}

Berdasarkan hasil analisis data dapat dikemukakan kesimpulan dari penelitian ini. Sebagai kesimpulan penelitian yaitu terdapat pengaruh yang berarti antara penggunaan LKS IPA Terpadu bermuat an keterampilan literasi tema gerak dalam kehidupan terhadap kompetensi siswa kelas VIII SMPN 8 Padang. Jadi, penggunaan LKS IPA Terpadu bermuat an keterampilan literasi tema gerak dalam kehidupan dapat meningkatkan kompetensi siswa mencakup sikap, pengetahuan dan keterampilan kelas VIII SMPN 8 Padang.

\section{UCAPAN TERIMA KASIH}

Terima kasih kepada Kemenristek Dikti RI atas Penelitian Produk Terapan 2017, No. Kontrak: 777/UN35/LT/2017. Penelitian ini merupakan bagian atau kombinasi dari penelitian tersebut. Terimakasih kepada semua pihak yang sudah membantu ter laksananya penelitian ini.

\section{DAFTAR PUSTAKA}

[1] Asrizal, Ali Amran, Azwar Ananda, Festiyed. 2017. Effectiveness of Adaptive Contextual
Learning Model of Integrated Science by Integrating Digital Age on Grade VIII Students. Icomsed, Vol. 2.

[2] M. Hosnan. 2014. Pendekatan Saintifik dan Kontekstual Dalam Pembelajaran Abad 21. Bandung: Ghalia Indonesia.

[3] Kemendikbud. 2015. Peraturan Menteri Pen didikan dan Kebudayaan Republik Indonesia Nomor 58 Tahun 2014 Tentang Panduan Pe nilaian Untuk Sekolah Menengah Pertama. Jakarta: Kemendikbud.

[4] Trianto. 2012. Model Pembelajaran Terpadu. Jakarta: Bumi Aksara.

[5] Depdiknas. 2008. Panduan Pengembangan Bahan Ajar. Jakarta: Direktorat Jendral Manajemen Pendidikan Dasar dan Menengah.

[6] Abdul Majid. 2012. Perencanaan Pembelajar an. Bandung: Remaja Rosdakarya.

[7] Pratiwi Retnaningdyah., dkk. 2016. Panduan Gerakan Literasi Sekolah di Sekolah Menengah Pertama. Jakarta: Direktorat Jenderal Pendidik an Dasar dan Menengah Kementrian Pendidik an dan Kebudayaan.

[8] Esti Aprilia Usman, Asrizal, Zulhendri Kamus. 2017. Pengembangan LKS IPA Terpadu Mengintegrasikan Literasi Saintifik dan Tugas Autentik Gerak Benda dan Struktur Jaringan untuk Siswa Kelas VIII SMP. Pillar of Physics Education, Vol. 9, 25-32.

[9] NCREL and Metiri Group. 2003. enGauge $21^{\text {st }}$ Century Skills: Literacy in the Digital Age. USA: NCREL and Metiri

[10] Putri Dwi Sari, Asrizal, Letmi Dwiridal. 2017. Pengembangan LKS IPA Terpadu Kontekstual Bermuatan Literasi Tema Pemanfaatan Kesehatan Pencernaan dalam Kehidupan Untuk Pembelajaran Siswa SMP Kelas VIII. Pillar of Physics Education, Vol. 10, 89-96.

[11] Ayu Triana, Asrizal, Zulhendri Kamus. 2016. Pengaruh LKS IPA Terpadu Berbasis Web dengan Mengintegrasikan Nilai Karakter pada Materi GLSTSGPS Terhadap Kompetensi Siswa Kelas VIII SMP 8 Padang. Pillar of Physics Education, Vol. 7,193-200.

[12] Ika Ayu Puspita, Sri Wahyuni, Yushardi. 2017. Pengembangan LKS (Lembar Kerja Siswa) Fisika Berbasis CTL (Contextual Teaching And Learning) untuk Meningkatkan Collaborative Skills Siswa di SMA. Jurnal Pembelajaran Fisika. Vol. 6, 376-382.

[13] Sugiyono. 2017. Statistik untuk Penelitian. Bandung: Alfabeta.

[14] Mulyasa. 2014. Pengembangan dan Implemen tasi Kurikulum 2013. Bandung : PT Remaja Rosdakarya.

[15] Deni Kurniawan. 2014. Pembelajaran Terpadu Tematik (Teori, Praktik, dan Penilaian). Bandung: Alfabeta. 